\title{
ANÁLISE MITOLÓGICA DE A BELA ADORMECIDA E DOZE REIS E A MOÇA NO LABIRINTO DO VENTO
}

\author{
Wilton Fred C. de Oliveira
}

Resumo:

\begin{abstract}
O trabalho a seguir é uma tentativa de mostrar o resgate do mito. Trata-se de um paralelo entre a obra "A Bela Adormecida ", de Charles Perrault, e a obra "Doze Reis

e a Moça no Labirinto do Vento" de Marina Colasanti. Trabalhamos a Simbologia numerológica existente tanto numa como noutra, baseados em Cirlot, Eliade, Jung

e outros. Através da numerologia procuramos mostrar a ponte exis-

tente entre as obras, quanto à visão que ambos os autores apresentam da mulher.
\end{abstract}

Perrault, através de sua obra, retrata a mulher passiva de sua época; Cola santi, por sua vez, contrapõe àquela uma nova mulher, dinâmica, ativa, que não está à espera de um príncipe que a acorde, que não aceita a imposição paterna, tampouco está ao sabor dos ventos.

Colasanti se utiliza de símbolos, de uma linguagem mítica para desmitificar, fazendo reviver o mito de forma magnífica, não para permanecer mito, mas para se con trapor ao mito de que a mulher deve ser passiva e submissa.

\section{A BELA ADORMECIDA \\ O Universo Significativo}

A história do homem tem sido, desde os primórdios dos tempos, escatológica, como o resultado da necessidade de uma ponte de ligação entre ele e o Céu. E a espera do renascer, para compactuar com os deuses em sua cosmogonia, tem feito com que o homem crie símbolos e cumpra rituais , muitas vezes inconscientes. "Assim fizeram os deuses; assim fazem os homens. Porque foi assim que fez o Povo Santo da primeira vez." (1) E como, segundo Eliade, essa irrupção do sagrado fundamenta o Mundo e O converte no que é; conseqüentemente, a obra literária, que está sujeita ao mundo, reflete esses mitos, e encerrando em si toda uma simbologia, mesmo que não esteja em estado consciente.

Ainda em suas obras "O Sagrado e o Profano", "Mito e Realidade" e o "Eterno Retorno", Eliade nos revela que o homem é cosmogônico e isso é possível notar mesmo nas tribos mais primitivas, na crença que têm do renascer. Para o homem é premente voltar o tempo para encontrar o ponto de partida; é necessário o caos para se obter uma nova ordem.

Nada se renova sem o ritual de passagem. Necessário é retornar ao embrião, a fim de fazê-lo renascer depois.(2) Para Eliade, em o "Mito e Realidade", a iniciação equivale a um segundo nascimento. 
criatura socialmente responsável e, ao mesmo tempo, culturalmente desperta. O retorno ao útero é expressado quer pela reclusão do neófito numa choça, quer pelo fato de ser simbolicamente tragado por um monstro, quer pela penetração num terreno sagrado identificado ao útero da Mãe-Terra." (3)

É a partir desses pressupostos que entraremos no mundo de "A Bela Adormecida" de Charles Perrault; texto brasileiro de Otávio de Medeiros; junto com o príncipe (símbolo do consciente) e buscaremos trazer a princesa ao consciente, desvendando os signos existentes nesta obra. $\mathrm{E}$ para melhor análise, buscaremos fazer o levantamento dos elementos que surgem, seguindo os passos dados por Tzvetan Todorov em sua "Introdução à Literatura Fantástica". Segundo este, os contos de fadas participam da literatura maravilhosa quanto ao gênero, porquanto a transformação da realidade através do mágico é perfeitamente aceita, não se fazendo necessárias explicações. É verossímil enquanto mundo recriado, não provocando nenhuma surpresa no leitor.(4) São esses signos e signos sobrepostos que criam um cosmo e expectativa a partir da mundividência de cada leitor. Aqui, cabe-nos trabalhar e desmembrar esses signos. (5)

\section{A ESTRUTURA DO CONTO}

Quanto ao gênero, conforme acima citado, classificamo-lo como maravilhoso, com base em Todorov. O narrador é de terceira pessoa, onisciente; a linguagem, pressiva-literária-mítica; e o espaço mitológico.

\section{O ELEMENTO DUAL E O TRINO}

"Era uma vez um rei e uma rainha ..."Demos os primeiros passos para desvendar essa floresta, esse tempo perdido do era uma vez. Um tempo e espaço indefinidos, onde tudo era perfeito. É a tentativa de nos instalarmos na fonte da realidade primordial, quando o mundo estava in statu nascendi.(6) Nessa realidade há um rei e uma rainha desconhecidos, arquétipos de um coletivo. É o passado remoto que predomina, portanto, é o subjacente que nos cabe despertar. Nesse momento somos chamados ao in illo tempore. Mas não nos é dado apenas o elemento dual-reirainha: os opostos Céu x Terra, ou seja, os elementos hindus proclamados quando ocorre um casamento, tempo em que o homem diz "que a mulher é a terra e ele é o céu."(7); também é requerido, na obra, um terceiro elemento: a princesa, para romper o dualismo entre as forças benignas e malignas: antagônicas. Esse terceiro elemento era premente para esse dualismo, tanto que é narrado:

"tão aborrecidos, que nem se pode imaginar. lam a todas as estações de águas do mundo, faziam promessas, romarias e devoções, empregavam todos os meios para obter filhos..." (8)

Será esse terceiro elemento que prestará o serviço de justificar a continuidade existente dos opostos e dar-Ihes equilíbrio; por isso buscarem, o Rei e a Rainha, tão ansiosamente, através de devoções, promessas e estações de águas esse terceiro elemento. Era a vida que estava inibida; logo buscarem na água o milagre da vida, porquanto aquela simboliza o primordial, a substância da qual surgem todos os elementos, inclusive os deuses.(9)

Esse terceiro elemento também passaria a simbolizar a influência do espírito sobre a matéria, do ativo sobre o passivo. Da mesma forma é o dual rei-rainha que necessitavam de um termo 
centro; é a alma e o corpo que exigem um espírito.

"Finalmente, um belo dia a rainha teve uma menina." (10)Surge, neste ponto, o terceiro elemento coordenador do dual, fazendo-se necessário o batismo que representará o renascer através das águas. Observemos o que nos cita Eliade: "...uma vez nascido, o homem ainda não está acabado; deve nascer uma segunda vez, espiritualmente; tornar-se homem completo passando de um estado imperfeito, embrionário, a um estado perfeito ..."(11) São os elementos corpo + alma + espírito que agora retornam ao princípio gerador, ao útero, repetindo a cosmogonia. E essa somente pode ser repetida através do ato do batismo. Eis por que o autor nos cita:

\section{"O batismo foi uma festa, e convidaram para madrinhas da princesa as fadas que se achavam no país, que eram sete .." (12)}

Para tal ato, como vemos na passagem transcrita, foram convocados sete elementos significativos: fadas, as quais são recebidas de forma honrosa: "Colocou-se diante de cada uma um magnífico estojo de ouro maciço..." (13) Este, segundo o "Dicionário de Símbolos", representa a luz solar, a inteligência divina e o coração. O que se pretende com isso é evocar qualidades superiores, para a princesa, dos bens espirituais e da iluminação suprema.

Mas é interessante observarmos que as fadas, que concedem dons a recém-nascidos, surgem em número de sete num primeiro momento, simbolizando os sete elementos, encerrando também a mesma Simbologia ternária, ou número somativo do Céu e da Terra. Como citamos no início deste trabalho, a princesa surge com essa mesma função: somativa do dual rei-rainha. Contudo a trama não para por aí:

"... no momento em que todos tomavam lugar à mesa, surgiu uma fada velha que não tinha sido convidada, pois fazia mais de cinqüenta anos que não saía de sua torre, razão por que a julgavam morta ou encantada."; (14)

criando-se, assim, o octógono - forma de batistério ou fonte, os quais simbolizam a regeneração espiritual. Mas como ela não era esperada

\section{"O rei ordenou que lhe dessem [à velha fada] um talher, mas não houve meio de lhe arranjarem um estojo de ouro maciço, pois havia apenas sete para as sete fadas." (15)}

Ainda, conforme o texto, segue-se: "A fada velha pensou que a desprezavam e resmungou algumas ameaças entre os dentes." (16)É neste sentir-se desprezada que a fada velha, ao invés de conceder à princesa um dom, parece amaldiçoá-la. Notemos aqui que a simbologia do ouro é muito significativa neste quadro, porquanto simboliza a perfeição e o batistério, bem como a perenidade. Isso nos leva a crer que uma parte do octógono era perecível e que o batismo seria impossível, face à ausência da oitava parte do batistério. Não havendo essa parte, ou em a havendo perecível, o processo cosmogônico tornar-se-ia impossível.

Porém, vamos antes à análise das fadas ou fiandeiras, e de seus dons concedidos; sem todavia nos esquecermos de que uma das sete fadas esconde-se, conforme passagem a seguir: 


\section{"Uma das fadas moças que se achava por perto, ouviu-a e pensando que ela poderia dar à princesa algum dom inconveniente, foi, ao saírem da mesa, se esconder atrás da cortina a fim de falar por último...",(17)}

assumindo a função do oitavo lado do octógono, enquanto que a oitava desloca-se para a sétima posição, fechando o batistério e possibilitando o ressurgir ou renascer da princesa após a imersão; ou para atenuar o mal do sétimo ângulo, o que tornaria impossível o fechamento numa sétima posição.

\section{A Simbologia Numérica das Fadas e seus Dons}

Ao fazermos a comparação numérica das fadas e dos dons concedidos, constatamos que cada uma delas não poderia vaticinar outra coisa além do concedido, haja vista a própria numerologia de que a fada era portadora o indicar. Observamos também que a primeira fada ou número "um", simbolizava o centro do cosmo (uno), e, por ser a mais nova, somente poderia estar ligada ao físico; daí, como primeira, deu-lhe o dom de ser a mais bela do mundo; ou seja, o centro das atenções, bem como ditou-lhe uma primeira fase egocêntrica, em que tudo para a criança gira em torno de si mesma. Constatamos isso na passagem: "Entrementes, as fadas começaram a conceder dons à princesa. Deu-Ihe a mais nova o dom de ser a mais bela do mundo..." (18)

A segunda, símbolo do "dual" ou binário, professa que" teria a inteligência de um anjo."(19) Notamos que o dual significa: " Todos os processos que possuem fases contrárias... ouro $x$ prata; sol x lua..." (20)Assim, tal voto dado pela fada, além de ter íntima ligação numérica, significava, também, a contradição beleza $\mathrm{x}$ inteligência; corpo $\mathrm{x}$ alma; céu $\mathrm{x}$ terra.

A terceira, ou "trino",por sua vez, vaticinara que a princesa "poria uma graça admirável em tudo quanto fizesse".(21) , vaticínio pertinente à fada, visto que o trino é o número da idéia ou organização espiritual. Tal voto também é condizente, porque se trata duma analogia: como soprou o Senhor nas narinas do homem dando-Ihe a vida, assim também se assemelhava o voto. Era o espírito ou a ânima que Ihe era soprado: a graça, a magia.

A quarta ou "quaternária" disse que a princesa "dançaria perfeitamente bem".(22) Notemos que o número quatro representa, consoante o "Dicionário de Símbolos", a realização da idéia; o mundo manifesto; corresponde à terra, à organização material; logo, a força de seu voto seria a de unir o espírito ao material: o Céu à Terra, a teoria à práxis.

A quinta (ou "quinário" é símbolo do homem depois da queda, da saúde e do amor na ordem terrena) professou "que a princesa cantaria como um rouxinol".(23) Cabe aqui observar que Pitágoras (560 a. C.) acreditava que os planetas estavam dispostos de tal forma que eles, como numa escala musical, emanavam sons, só que os ouvidos humanos não percebiam por estarem acostumados a eles; vindo mais tarde ainda, na metade do séc. IV a.C. Arquitas de Tarento transformar os estudos daquele em uma complexa teoria musical.

Quanto à questão do rouxinol, registramos que pássaros representam a alma que, decaída, encontra-se presa, a cantar de seu cárcere. (Lembremos Cárcere das Almas, de Cruz e Souza.) Cremos que os significados expostos quanto ao número cinco tenham estreita ligação entre a posição ocupada pela fada e seu voto de cantar como um rouxinol. Primeiro porque o número cinco simboliza a música, bem como o rouxinol; segundo porque a princesa, como todos os seres humanos, é alma decaída que encarna, conforme cita Platão em "O Mito dos dois 
A seguir, a sexta fada determinou que " caberia tocar toda espécie de instrumentos, com o máximo de perfeição". (25) Contudo, surge-nos um impasse quanto à significação deste número. Na teologia ocidental, o número seis é símbolo da imperfeição e representante do demônio, enquanto o número sete, de Cristo. Outrossim, no sexto dia o Mundo estava acabado, perfeito. Novo impasse; o que nos leva novamente à teoria pitagórica.

Para Pitágoras os números são envolvidos em grande misticismo e relações ocultas, uma espécie de numerologia mágica sem qualquer significado científico.(26) Havia para ele um grupo determinado perfeito e que os números 6 (seis), 8 (oito) e 12 (doze) estavam em progressão harmônica; por exemplo, o cubo estava em harmonia geométrica porque tinha seis faces, oito ângulos e doze arestas; e essa mesma progressão foi que o embasou para desenvolver a sua teoria musical. Somente através da numerologia pitagórica é que podemos justificar a sexta fada e o voto dado à princesa de tocar todo e qualquer instrumento de forma perfeita. Quanto ao instrumento, lembremos aqui que o violão é composto de seis cordas, bem como no piano as cordas são arranjadas em grupos de três.

\section{O Problema Numérico}

Como citamos anteriormente, a sétima fada havia cedido lugar à oitava. Não nos esqueçamos de que o sete ou setenário, por suas virtudes ocultas, tende a realizar todas as coisas; é o dispensador da vida e fonte de todas as mudanças, tal qual a Lua, que muda de fase a cada sete dias. Cremos estar aí o segredo da troca. Tanto que:

\section{"...chegando a vez da velha fada, disse ela, balançando a cabeça, mais por despeito do que por velhice, que a princesa espetaria a mão num fuso e viria a morrer." (27)}

Para ditar tal vaticínio, como controladora da vida, teria que ocupar a sétima casa, o que estaria condizente com o significado do número sete; e também condizente com o meio e instrumento do qual ela se utiliza para vaticinar: o fuso. Sendo as fadas fiandeiras, somente poderiam utilizar-se do fuso que , segundo o "Dicionário de Símbolos", significa Céu x Terra, e também significa o sacrifício mútuo que renova a força do universo, símbolo da Magna Mater. Portanto, a princesa, que surge como renovação rei-rainha ou Céu x Terra, não cumpriria seu destino, pois seria fatalmente interrompido quando, da posição de Magna Mater, estivesse a tecer a renovação do cosmo ou quando estivesse apta para tal. Não nos esqueçamos, também, de que o fuso é símbolo da vida e da duração e que, em outros termos, poderia significar que a princesa poderia falecer quando se desse a sua primeira cópula.

Observemos a oitava fada, que era a mais nova e ocupava a sétima casa, anteriormente diz:

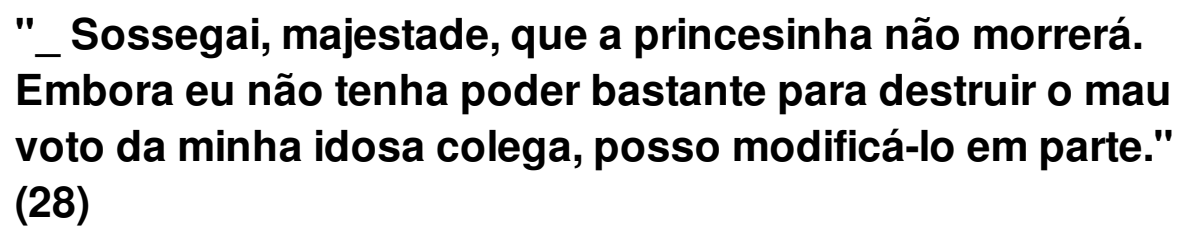

Num primeiro plano o que nos é perceptível é a obrigatoriedade do jovem ter que se render ao velho, isto é, ou ao princípio caótico. A renovação somente se daria com o retorno da princesa 
aos primórdios; por isso sentenciou-lhe a fada mais idosa, a oitava parte do batistério, (então sétima) à imersão. Mas o novo, que representa a força restauradora - representada pela fada mais nova - não podendo evitar o caos, podia, no entanto, organizá-lo.

Observemos também que o oito, como reforço ao exposto, simboliza a regeneração espiritual, e, miticamente, tal regeneração, segundo Eliade, equivale a um segundo movimento, no qual se dará o ritual de passagem da princesa. É a volta ao útero, à imersão cristã, da qual a princesa estava condenada a não emergir, é que foi atenuada. Como Jonas, ficaria por um determinado tempo, imersa, mas emergiria.

Ainda dentro da questão numérica, nesta primeira etapa, temos a questão do vaticínio da oitava fada:

\section{"A princesinha apertará a mão num fuso, mas em vez de morrer cairá em sono profundo por cem anos." (29)}

Intrigados com a questão dos cem anos, retornamos a Pitágoras, porquanto nos parecia ser, de imediato, a única teoria a responder satisfatoriamente. Por que cem anos?! Se o número

(dez), devido aos quatro pontos de cada lado, era chamado de Tetractys, e considerado sagrado, porque simbolizava a forma trina: rei + rainha + princesa. A princesa, portanto, surge como um elemento apaziguador de contrários, deixando ser 'una", ou seja, não tendo características próprias. Ela somente existe enquanto elemento unificador do dual, não possui individualidade, isto é, características próprias. Ela não tem sua própria unidade, porquanto ela é, enquanto parte de uma trindade.

Como torná-la una e desprendida dessa forma trina, para que viesse manter a sua individualidade e pudesse também exercer a função de Magna Mater, ou renovadora do cosmo dual rei e rainha? Condenando-a a dormir cem anos; ou seja: se o número 10 é perfeito, porque contém em si a trindade, ou todos os números em si, e $1+0=1$, retornando-se ao uno, logo a progressão aritmética $6+8+10$ que para Pitágoras é perfeita, porque o 10 encerra em si o dual 6 e 8 ; se elevarmos, $62+82=102$, ou $36+64=100$, teremos o seguinte resultado: $1+0+0=1$. Única forma de restaurar a individualidade da princesa ou torná-la una. (30) Salientamos também neste que o mesmo concebia um sistema planetário com oito planetas, dando a cada planeta um nome mitológico, o que nos remonta ao número das fadas. (31)

Ritual de Passagem: o Vaticínio

\footnotetext{
"Ao fim de quinze ou dezesseis anos, tendo o rei e a rainha partido para uma de suas casas de repouso, aconteceu que a jovem princesa, percorrendo de quarto em quarto, subiu até $o$ alto de uma torre, onde encontrou uma velha sozinha, fiando em uma roca." (32)
}

Aqui chegamos ao fecho da primeira parte e abordaremos alguns elementos essenciais da 
passagem transcrita de "A Bela Adormecida" de Perrault.

Novamente surgem os números. O texto é claro e já inicia: "Ao fim de quinze anos..." Tal número fez com que ziguezagueássemos pelos quatro cantos do mundo. Observamos que o número quinze e o dezesseis marcavam exatamente o período em que a mulher se tornava fértil. Essa era a idade de transição de menina em mulher. Nascia aí o período em que a menina era integrada ao grupo de mulheres aptas para se tornarem Magna Mater. Em oposição a essa transição, temos a do homem judeu, como exemplo, que somente era socialmente responsável aos trinta anos, idade da razão. Notemos que Cristo batizou-se somente aos trinta anos e $15+$ $15=30$, ou $3+0=3$, ou forma trina, ou $1+6=7$, número da fada que a vaticinara, ou número da mudança.

Outro fator observado foi o fato da princesa entrar em quartos. Na versão de Walt Disney, a princesa não só entra, mas gira uma chave de ouro. A chave, segundo o "Dicionário de Símbolos", significa que o espírito abre as portas do céu; também é o símbolo da iniciação ao saber. (33)Não nos esqueçamos de que o céu representará o sexo masculino, bem como a chave; já o quarto, o feminino. Isso nos leva a crer que aqui se dá o seu ritual de infância para a maturidade de mulher apta a se tornar uma Magna Mater. É nessa exata idade que o vaticínio se cumpre:

\section{"Mas nem bem apanhou o fuso, ele ... espetou a mão e caiu sem sentidos." (34)}

Notamos também que tal curiosidade da princesa é pertinente à criança, e não ao adulto, quanto ao vasculhar o quarto e querer saber o que fazia a velha, bem como tomar imprudentemente nas mãos o fuso. Outro símbolo que comprova tal passagem é que a princesa subiu ao alto de uma torre, símbolo do elevar-se acima da norma vital ou social, ou por seu aspecto fechado, é emblemático da virgem.(35) Aqui temos o ponto culminante, ou momento em que se dá o seu mênstruo. E a seguir à página 34 cita: "O desmaio não conseguira desbotar as vivas cores de seu rosto: suas faces eram vermelhas..." Novo símbolo de mênstruo.

O Sono e os Símbolos

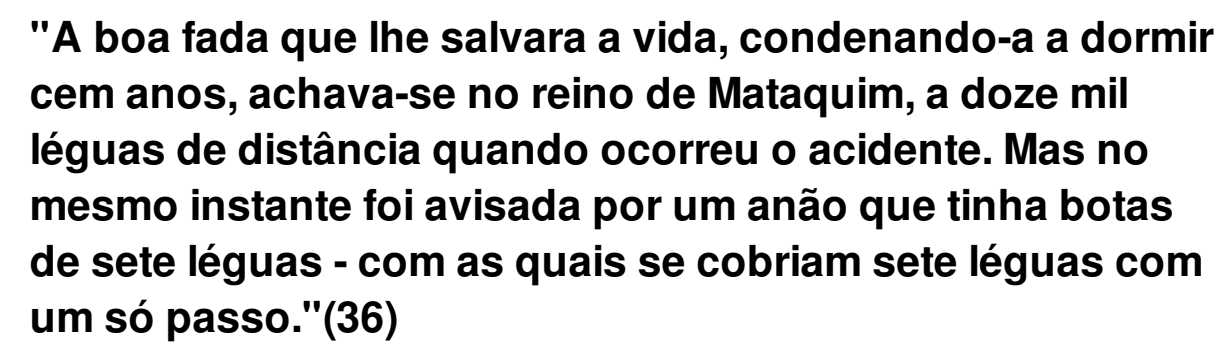

Na passagem transcrita vemos que os números ainda permanecem como fonte simbólica deste conto. Por que em doze mil léguas e a sete léguas? Primeiro, segundo Cirlot, o número doze "divide o dia, representa os deuses gregos, e também o círculo mais elevado e próximo ao centro misterioso se compõe de doze membros, que representam a iniciação suprema (potestades, virtudes, conhecimentos) e que correspondem à zona zodiacal."(37) O que tem estreita ligação com o ritual de passagem da princesa. Observemos que são cem anos e os anos são compostos de doze meses, e também quanto à questão do centro e do conhecimento, o que comprova a nossa teoria dos cem anos com base em Pitágoras, do retorno ao uno. Se o doze é o círculo mais elevado e próximo ao centro, é este centro que cabe à princesa ocupar. É 
a virtude e conhecimento de Magna Mater que lhe cabe arcar.

Num segundo plano, temos o número sete e o anão, que ainda Cirlot nos cita: "é o símbolo dos poderes que ficam fora da consciência, ou os guardiões do umbral do inconsciente".(38) Quanto ao número sete, como já explicado anteriormente, é o dispensador da vida e a fonte de todas as mudanças. Mas não ficamos somente aí, notamos que o texto diz: "... as quais cobriam sete léguas com um só passo." Vimos que o número sete é a fonte de todas as mudanças, por isso, a oitava fada que antes era a sétima, agora retorna do sétimo ângulo, que estava rompido, proporcionando à princesa a mudança. Outrossim, se o número doze também é circular (segundo Cirlot), lembremos que cabia a ela fechar o octógono em sua sétima posição, como já citamos anteriormente, por isso estar a doze mil léguas, por isso as sete léguas em um só passo. É a mudança sofrida pela princesa em seu inconsciente que a conduzirá ao uno. É o inconsciente agora representado pelo anão, que prevalece, tendo em vista que o consciente adormeceu.

A seguir Perrault cita: "A fada logo partiu e dentro de uma hora viram-na chegar numa carruagem de fogo, puxada por dragões." (39)Ao consultarmos o "Dicionário de Símbolos" verificamos que o carro é símbolo do sétimo arcano do tarô e encarna os princípios da personalidade humana, além de significar a separação entre o absoluto e o relativo.(40) Temos então a sétima fada simbolizando o sétimo arcano. Notamos que condiz com o que observamos antes e reforça a teoria numérica levantada neste trabalho, quanto à troca das posições, bem como ser ela a única a poder fechar o batistério, confirmando também a teoria, já desenvolvida neste trabalho, sobre o jovem e o velho. É o processo cosmogônico que se processa.

Lembremos aqui Eliade: "Aquele que volve atrás no tempo deve necessariamente reencontrar o ponto de partida que, definitivamente, coincide com a cosmogonia."(41)

Outros símbolos acima citados reforçam nossa teoria, tais como: em uma hora, novamente a idéia do uno. O fogo expresso através da carruagem. Cita-nos Cirlot quanto ao fogo:

"...a idéia de vida e saúde (calor no corpo) ... e isto nos
indica uma transformação do símbolo a uma energética
espiritual, com a idéia de superioridade e mando. É o
germe que se reproduz nas vidas sucessivas (associação
à libido e à fecundidade). O fogo se assemelha à água; é
também um símbolo de transformação e regeneração. É a
vitória contra o poder do mal (as trevas); a purificação é o
meio sacrificial necessário para que se triunfe... O fogo é
um elemento que atua no centro de toda coisa, "fator de
unificação e fixação. (42)

Sugere o desejo de destruir o tempo e levar tudo a seu final. Vejamos o que nos cita Mircea em "O Sagrado e o Profano": "A imersão repete o gesto cosmogônico da manifestação formal: a imersão equivale a uma dissolução das formas. É por isso que o simbolismo das águas implica tanto na morte quanto na renascença" (43)

Antes de fazermos a união dos elementos dados, voltaremos a Cirlot quanto ao significado do dragão. "Relaciona-se com o princípio do caos. É a dissolução dos corpos."(44)

Assim como Cristo foi ao Hades ressuscitando ao terceiro dia, assim se processa a princesa. 
Assim como o Virgílo vai ao Hades, assim vai a princesa. É o corpo sendo puxado pelo espírito, conduzindo-o à dissolução para a purificação. $O$ fogo que purifica e regenera e une os elementos, o sacrifício necessário para se ter a unidade. É a volta ao caos na figura do dragão em busca do renascer. Em outros termos: e imergiu a princesa e todo seu mundo consciente. "E tocou a fada com sua varinha e tudo e todos adormeceram..."(45) Deu-se início a transformação da menina em mulher. Tanto que temos na seqüência:

"... pois dentro de um quarto de hora nasceu e cresceu em
redor do castelo grande quantidade de árvores, cipoal e
espinheiros entrançados de modo que nenhum homem
nem bicho poderiam jamais entrar ali. No meio do matagal,
apenas se avistavam as pontas das torres, embora só de
muito longe." (46)

O texto em destaque aborda a parte em que a fada retorna a fim de preparar o ambiente para quando se desse o despertar da princesa. Na tentativa de protegê-la, a boa fada fez crescer em torno do castelo grande quantidade de árvores. Estas vêm colaborar em significação para o até aqui exposto; também a torre que somente ao longe se avista. As árvores representam a vida do cosmo, crescimento, proliferação e regeneração - centro do mundo. Cita-nos Cirlot, as mesmas são:

. "...imagem verticalizante, pois conduz uma vida
subterrânea até o céu; símbolos da relação entre os três
mundos ( inferior ou infernal; central, terrestre ou da
manifestação superior, celeste). A árvore coincide com a
cruz da Redenção, e na iconografia cristã a cruz está
representada como árvore da vida. (...) como eixo do
mundo. (...) Símbolo do processo evolutivo, de todo o
crescimento de uma idéia, vocação ou força." (47)

O centro nevrálgico até então tem sido a princesa como unificadora do dual ou dos opostos. Tanto que toda a simbologia sempre está relacionada com Céu x Terra ou com outros elementos opositores. Quando citamos anteriormente que o vaticínio da oitava fada estava relacionada ao renascer de Eliade, ao mito cosmogônico, vimos que em nenhum momento a simbologia numérica existente contrariou a nossa primeira exposição. Era necessário retornar ao uno, e novamente o círculo se fecha comprovando a nossa tese mítica de unificação através da simbologia das árvores. É a princesa que vai ao Hades, ao caos, em busca da redenção. É o seu mundo subterrâneo, como mulher, que vem à tona. O processo evolutivo que se realiza e se entrelaça em forma circular unificando ou se tornando centro.

Não nos esqueçamos também de que a boa fada, ao ocupar a oitava casa, tinha por intenção fechar o círculo caso ele rompesse, retornando posteriormente de sétima posição; e, o que constatamos através das árvores é exatamente o fechamento desse círculo propiciando o ritual de passagem.

\section{O Príncipe e a Redenção}

Até a presente etapa coube-nos apenas tentar decifrar a simbologia que envolvia a nossa heroína, a qual não se situava numa posição ativa, porquanto simplesmente sofria a ação de 
forma apassivada. Sua única ação foi tomar do fuso; mas mesmo aí, cumpre simplesmente aquilo que "O oráculo de "Delfos", o qual não diz nem oculta nada: significa". (48), na forma da fada. E aqui entra novamente a velha fada como um oráculo significante que não rogou sobre a princesa nenhuma praga, nem tampouco Ihe traçou nada: significou.

Para completar o significado, o simulacro da vida surge o nosso herói: ..."Ao completarem os cem anos o filho do rei que então reinava..."(49) Se em algumas versões, como a de Disney, a estória tem seu fim ao ocorrer o despertar da princesa após o contato com o príncipe, nesta versão de Perrault temos ainda muito a analisar quanto ao comportamento daquele. De imediato nenhum ritual sofre o príncipe. O cenário se abre dando-lhe passagem, porquanto se sentia destinado e estava com o coração cheio de amor por algo que desconhecia.

Retomemos a narrativa.

\begin{abstract}
"Ao completarem os cem anos, o filho do rei que então reinava e que era de outro ramo da família, indo caçar por aquelas bandas, perguntou o que significavam as torres que via despontando por cima da espessa mataria." (50)
\end{abstract}

Dois símbolos são de suma importância na passagem transcrita. A torre, em que propositadamente não nos detivemos anteriormente, e a questão da caça.

Baseados em Cirlot temos: "Caça representa a busca muito apaixonada, porém se relaciona mais com a idéia de fazer presa ou mesmo vítima."(51) "Torre: ação de elevar-se acima da norma vital. Por seu aspecto fechado, murado, é emblemático da virgem." (52)

Notamos que o comportamento do príncipe como nos comprova certos trechos é imaturo e que 0 mesmo está movido pela ansiedade púbere do adolescente. Tanto que nos cita o texto que estava a caçar, ou simbolicamente, em busca apaixonada. Prova do nosso argumento é que o que desperta o interesse dele são justamente as torres, as quais representam a virgem. Sua curiosidade era tão intensa que procurou informar-se do que existia lá. Apesar das informações obtidas quanto à existência de bruxas, etc., não se acovardou conforme nos cita o texto:

"Continuou a caminhar, porque era valente e estava com o coração cheio de amor." (53)Ainda: "Entrou afinal num grande pátio onde tudo o que viu era bastante para enregelar de medo qualquer pessoa." (54), mesmo assim não se intimidou, já que era maior o seu desejo que o seu medo. Caminhou por aquele mundo desconhecido até deparar-se com a princesa diante da qual ficou extasiado a ponto de ficar trêmulo e se ajoelhar de admiração; atitude essa que revela a sua imaturidade, pois rendeu-se ao primeiro amor. Cita-nos o texto: "Todo trêmulo, o príncipe se aproximou e, cheio de admiração, ajoelhou-se perto dela." (55)

Após despertar, a princesa lhe pergunta:

"_És tu meu príncipe? Como tardaste a vir!"(56)

"Encantado com estas palavras e mais ainda com o tom amoroso com que foram ditas, ficou o príncipe sem saber como demonstrar a sua felicidade. Por fim, declarou à jovem que a amava mais do que a si mesmo." (57) 
Todo o comportamento do príncipe converge sempre para o mesmo ponto - a caça. O desejo o encantou e o levou inclusive a declarar um amor acima de si mesmo. Estava seduzido e era preciso seduzir.

Ao mesmo tempo que a princesa, despertam todos os serviçais e a seguir, em festa, o sacerdote do palácio realiza o casamento de ambos, os quais se recolhem, em seguida, aos seus aposentos. Novamente o comportamento do príncipe se processa de forma instintiva, tanto que o casamento ocorre sem a prévia comunicação aos pais e num primeiro contato, o que ele vem ocultar à família, mantendo a princesa no castelo dela, indo vê-la, utilizando-se sempre do pretexto de ir à caça; dando, a posteriori, justificativas aos pais, atitude que também revela a sua imaturidade.

E assim o príncipe conduz a sua vida familiar camuflada por um período de dois anos, apesar da desconfiança da mãe. Mas "A rainha tentou fazer seu filho contar o segredo daqueles mistérios. O príncipe, porém, nunca se atreveu a satisfazer sua curiosidade." (58)

Notemos aqui que a estória se divide em duas etapas. A primeira é o ritual de passagem da princesa e a segunda, do príncipe. Se ela estava apta, tanto que ao acordar diz: "És tu meu príncipe?"; ele, ao contrário, havia agido de forma inconsciente, tanto que ainda estava apegado à bruxa mãe o que o levava a não confessar a vida paralela que vivia.

Cita-nos Jung: "Sem que obtenha um certo grau de independência, o indivíduo será incapaz de relacionar-se com seu ambiente adulto.(59) Ele não tinha desenvolvido a sua consciência a ponto de guardar a sua individualidade em seu meio. Está sob a figura arquetípica do pai compreensivo e da mãe-bruxa. Tanto que cita-nos Perrault: "O rei, seu pai, que era homem bom acreditou na história, mas a rainha mãe não ficou muito convencida." (60)E é a partir da morte do pai, ao ascender o príncipe à condição de Self, ou arquétipo de um social, é que se dará o conflito. Não estando capacitado para assumir-se como arquétipo, haja vista não estar em estado Self, vê-se dominado pela sua ânima. Prova disso é que ele só traz para seu reino a princesa e seus dois filhos ao assumir a postura de rei; contudo ele está sob a sombra da mãe, tanto que cita o texto: "Um ano mais tarde teve o novo rei de fazer guerra a um reinado vizinho. Ao partir deixou a regência entregue à rainha-mãe, muito the recomendando a sua mulher e seus filhos." (61)

Como citamos antes, o príncipe fora precipitado no agir, instintivo. Segundo Marie-Louise, "quando um homem não tem relação alguma com os seus níveis mais profundos de sentimento e emoção, a ânima para ele não vive, ele tem apenas uma perspectiva ética."(62) É esta ética que irá fazer com que o novo rei leve a princesa para o seu castelo, e a assuma, eticamente, não emocionalmente. É a partir daí que, não tendo profundidade o seu sentimento, a princesa não ocupa o trono e sim a mãe. A terrível ânima que o domina a ponto de, consoante o texto, ser descrita: "Diziam mesmo na corte que o sangue bruxo que lhe corria nas veias era tão forte que ela não podia passar perto de uma criança sem devorá-la." (63)Citamos também que a mãe buscava saber de suas andanças, ou seja, era extremamente controladora e castradora de seus atos o que levará o novo rei a se retirar, supostamente, para uma batalha, ou seja, introjetar-se em conflito. É neste momento que ele sofre o seu ritual de passagem interno de aceitação ou negação de seus atos. Vejamos Cirlot: "Luta é a exposição de um conflito. É um morrer e ressuscitar." (64)

Essa luta será travada através da imagem da mãe, conforme nos cita o texto: "E depois que ele partiu, enviou a nora a uma casa de campo e os filhos..."(65) Em outros termos, renegou-os, 
iniciando assim o conflito de aceitação ou não, ou de permitir que prevalecesse a mãe em si. Tanto que o texto aborda que a bruxa ordenou ao mordomo que matasse a menina Aurora porque queria comê-la. Depois de algum tempo ordenou que matasse o menino e por fim a princesa.

Segundo o significado que Cirlot atribui ao termo devorar, ao confrontarmos com a obra vemos que antes de se tratar de um devorar no sentido literal, tratava-se do medo do príncipe, então rei, de ser devorado, pela mãe". (66)Com isso desencadeou-se, no rei, um processo de maturação conduzindo-o ao estado Self . Não sendo possível dominar o seu inconsciente, de maneira que viesse a estar preparado para as difíceis tarefas da vida, o elemento da obra, o guardião, surgiu a fim de desenvolver no rei a consciência do Ego, evitando assim a destruição interna da figura da princesa e dos filhos.

Descoberto o engodo a rainha mãe sentencia o mordomo, bem como a princesa e seus filhos a serem lançados em uma tina repleta de serpente, símbolos do inconsciente destrutivo. No momento fatal surgiu o rei, que todos pensavam estar morto, e sem saber o porquê de toda aquela azáfama, perguntou aos que lá se encontravam o que estava a ocorrer, ou seja, era a hora fatal em que ele tinha que assumir e trazer para si a sua verdadeira ânima, a qual o conduziria ao seu estado Self. Mais abaixo, cita-nos Perrault que: "A rainha bruxa, furiosa, de ver o que via, atirou-se ela própria na tina e foi devorada num minuto..." (67)É a mãe que posta em um segundo plano, morre para o consciente e deixa de influenciá-lo, por isso lançar-se na tina de serpentes, ou seja, ir para o inconsciente, passando agora, o rei, à aceitação de sua mulher e de seus filhos; assim finalizando a obra:

\section{"O rei não deixou de ficar aborrecido: a rainha velha era sua mãe, mas logo ele bem depressa se consolou com sua bela mulher e filhos." (68)}

\section{DOZE REIS E A MOÇA NO LABIRINTO DO VENTO}

\section{A Herança Mítica}

Quando, em entrevista ao professor Garzuzi, presidente do Instituto Neo-Pitagórico, ouvimos: "Somos herdeiros da Humanidade." E após várias leituras da obra "Doze Reis e a Moça no Labirinto do Vento" de Marina Colasanti, objeto de nosso estudo; constatamos que o homem, como nos cita Eliade, se comporta sempre como os antepassados, e seus atos são um comungar com toda a criação. Vemos renascer os mitos de iniciação neste conto e percebemos, através da simbologia, que passaremos daqui por diante a analisar, que o homem carrega sobre seus ombros toda a herança dos antepassados. Herdamos deles o nosso comportamento e a nossa essência, e nos unimos na mesma crença mítica. Somos a Humanidade, porque segundo Fustel Coulanges:

\footnotetext{
"Nada de mais poderoso existe sobre a alma. E essa coisa é a crença. A crença é a obra de nosso espírito, mas não encontraremos nele liberdade para modificá-la a seu gosto. A crença é de nossa criação, mas a ignoramos. É humana e a julgamos sobrenatural. É efeito do nosso
} 
próprio poder, e é mais forte do que nós. Está em nós, não nos deixa, e cada momento nos fala. Se nos manda obedecer, obedecemos; se nos indica deveres, submetemo-nos. $O$ homem pode dominar a natureza, mas está sempre sujeito ao seu próprio pensamento." (69)

E esse sujeitar-se à crença, num espaço secular, repete-se neste conto, porque está no Homem, pode ser obra de seu espírito, mas é mais poderoso que este, e esta crença volta cosmogonicamente a ressurgir consciente ou inconscientemente na obra de Colasanti.

"Trezentos e sessenta e cinco quinas bem aparadas tem $o$ labirinto de fícus no meio do jardim." (70)

Assim se inicia a obra, já carregada dessa crença mítica. Quatro elementos se nos surgem: o ano, o labirinto, a figueira e o jardim. E ao buscarmos o significado desses termos em Cirlot constatamos que:
"O ano é o protótipo do processo cíclico; o labirinto tem por missão defender o centro, quer dizer, o acesso iniciático à sacralidade, como perda num mundo que é equivalente ao caos; a árvore (fícus): a vida do cosmo, sua densidade, crescimento, proliferação, geração e regeneração; coincide com a cruz da redenção; o jardim constitui um símbolo da consciência frente à selva (inconsciente), um atributo feminino." (71)

Retornamos ao ritual de passagem, à herança da Humanidade. Novamente temos a nossa heroína como centro, a sofrer um processo ritualístico. Todavia difere o seu comportamento de "A Bela Adormecida". Se nesta a heroína está apassivada, em Doze Reis... a heroína se iguala ao mito de Talanta.(72) Não é a mulher que desconhece as suas etapas e que exerce um papel de inconsciente. Num primeiro momento ela é protegida pelo pai através da criação do labirinto, mas a personagem quer saber o porquê da proteção; tanto que ela lhe pergunta:

\section{"- Para que o labirinto, meu pai? \\ - Para domar o vento - responde o pai." (73)}

Se o vento é "o poder fecundador e renovador da vida", (74)isso simboliza que o pai, sabedor de que ela não havia sofrido seu ritual de passagem, a protege. Não nos esqueçamos de que a figura do pai representa o consciente e o poder controlador.

Ao começar a perguntar sobre a realidade que a circunda, começa o processo de autoconhecimento. Ela vê, desperta; não dorme. E o que vê são "Doze nichos de azulejo têm no fundo do jardim. E em cada nicho um rei barbudo, de mármore.

Ao que ela pergunta:

"_Para que os reis, meu pai?

_ Para casar contigo, milha filha, quando chegar a hora." 
Observemos que o número doze significa "a ordem cósmica, salvação"(76), o que nos conduz à idéia de ritual, e, cônscio disso, o pai tece a redenção da heroína. Como citamos anteriormente, os números doze e oito, segundo Pitágoras, são perfeitos. Se o oito simboliza o batistério, notamos que o doze tem aqui a mesma função. Mais abaixo o texto é descrito: "De olhos fixos sempre abertos, olham distante de si os reis barbudos."(77) Cirlot aponta o olho como uma parte do corpo que tem autonomia de caráter, bem como a multiplicidade de rostos e de olhos aludirem à decomposição contraposta à vontade mítica de integração no Um.(78) Não nos esqueçamos também de que o pai "representa o mundo dos mandamentos e das proibições morais, que põe obstáculos à instintividade e à subversão por expressar também a origem". (79)

Em contraposição a esse obstáculo que é o pai, temos os olhos os quais marcam a autonomia da heroína. Tanto que após passarem os anos, sentindo-se apta, ela declara ao pai:

\section{"_Este ano, meu pai, sem falta, vou me casar."(80)}

Ela não se rende às proibições paternas, sabe qual é o seu momento e este é expresso através do ano que novamente é citado. "Não olha para os reis. Mas é para eles que fala, porque o ano é novo e a hora chegou." (81)

A heroína avisa ao renovador do cosmo, o rei, que o ano é novo e a hora chegou; que ela está apta para recebê-los, que é una e necessita do seu oposto. Porém, se em "A Bela Adormecida", há a aceitação passiva e já destinada, aqui não. A mulher não irá submeter-se ao primeiro que chega, mas também, exercerá a sua autonomia na escolha. Imporá condições para a aceitação.

E assim se desfez a rigidez do primeiro rei. "Hora do primeiro rei..." ou "ocasião da ação humana."(82) Contudo, apesar de haver aquele pedido sua mão em casamento ao pai, ..."não é o pai que responde." (83)

"_Caso com aquele que souber me alcançar - grita a moça do labirinto." (84)

Mas o número um que é "um reino absoluto, fechado em si mesmo, não admite o dois nem dualismo"(85) e assim vem o rei lento e tardo sentindo ainda no corpo o peso da estátua e perde-se entre as quinas, petrificando-se, ou retorna a si, tornando-se incapaz de desvendá-la, porquanto está fechado em si mesmo. Ele não aceita a insubmissão dela tanto que, tradicionalmente, dirige-se ao pai; contudo, fechado em seus próprios valores, não admite a imposição e perde-se entre as quinas e petrifica-se, ou em outros termos - pasma.

Passa-se o primeiro mês. "À espera de que o chamado venha tirá-lo da sua imobilidade olha o segundo rei para a moça, enamorado. (86)

Novamente temos a imobilidade do rei, que aguarda o poder decisório da moça, e, ao contrário de "A Bela Adormecida", é o rei quem dorme. Ela ocupa a função de consciente (príncipe), já que o rei é símbolo do inconsciente coletivo. $E$ eis que chega a vez do segundo rei; "E o rei desce do nicho disposto a conquistá-la. Traz um galgo preso na coleira."(87) Ao consultarmos o "Dicionário de Símbolos", verificamos que galgo simboliza: "guardião e guia do rebanho, sendo 
alegoria, às vezes, de sacerdote"(88), e o número dois: "eco, reflexo, conflito, contraposição..." (89)

O segundo rei também não Ihe seria propício, tanto que o cão e o rei voltam a petrificarem-se, porque o número dois a levaria à submissão ou à imagem e reflexo paterno; o que não condizia com a sua autonomia.

E assim, vem o terceiro, símbolo de união do dual. Só que ela não necessita desse terceiro elemento unificador e com ele ocorre a mesma coisa que com os outros.

\section{"Seis meses se foram. E seis reis. No ar frio de inverno avança o sétimo, valente, arco e flechas ao ombro. "_Caso com aquele que cortar meu caminho - atira-lhe a moça sem pressa, à entrada do labirinto.' (90)}

Se o arco simboliza "a idéia de tensão" e a flecha "tem um sentido fálico inegável"(91), e o rei não consegue acertar o centro, apesar das diversas tentativas, haja vista a sua tensão, cremos que diante da segurança da moça, ele vem a falhar ou a se tornar impotente em desvendá-la: "E parte a flecha rumo ao rumo da moça. Mas não é ao rumo que chega." (92)

Notamos que a moça não aceitou os arquétipos ou modelos de homens apresentados. Até aqui, três arquétipos são trabalhados no conto: o homem fechado em si mesmo, ou que traz a falsa concepção machista; o que Ihe seria um pai, ou aquele que se mostra impotente ante a segurança da mulher atuante.

E sucessivamente, mês a mês, vão os reis tentando e imobilizando-se até chegar ao décimo segundo mês, e ao rei correspondente.

\section{"Último rei de bela barba avança, espada na mão. _ Com o homem que desvendar meu labirinto, só com esse casarei - diz ela procurando-lhe o olhar. E devagar some entre os muros verdes." (93)}

Vejamos alguns elementos que nos darão apoio para concluirmos tal episódio e o porquê se deu a aceitação da moça. Cabeça; "É a imagem do mundo. Significa o céu ou símbolo de emancipação." (94)Espada: "signo de liberdade e força; continuidade da vida; fecundidade, símbolo fálico; comando elevado de alta hierarquia."(95) Doze: "ordem cósmica, salvação." (96)

Se levamos, também em conta a posição do rei ou casa que ele ocupa, vemos que se trata da décima segunda casa ou último mês do ano em que finda o ciclo. O número doze segundo Cirlot, representa "ordem cósmica, salvação ou círculo"(97). Portanto o ciclo da heroína finda, renovando-se o cosmo, tanto que por último ela diz que somente se casará com o homem que desvendar seu labirinto, ou seja, elemento centro. Ela já está apta, haja vista que seu ciclo está completo. Observemos que o rei, que se apresenta, é um inconsciente coletivo emancipado, que não se trata de um príncipe inseguro. Além disso, temos a espada que nos mostra que o rei não se inibe com a segurança da moça: "com toda a força que séculos de mármore lhe puseram nas mãos, desembainha a espada... abate, arranca... Vira o vento escapando pelos raigos..."(98) E por fim, desvendada, não existindo mais o labirinto, haja vista a destruição dos fícus por parte do rei, cria-se o caos, para o renascer de Eliade, renova-se o cosmo, criando-se assim uma nova 
ordem.

\section{CONCLUSÃO}

Ao findarmos as análises de "A Bela Adormecida "e "Doze Reis e a Moça no Labirinto do Vento", verificamos que apesar do grande mar que as separa, o mito permanece presente, determinando as relações entre indivíduos, até os nossos dias, porque, "É criação do Homem, mas é mais poderoso que Ele". Consciente ou inconscientemente Marina Colasanti, repete a cosmogonia existente na obra de Perrault. A numerologia, trabalhada por ela em sua obra, remete-nos à mesma existente em "A Bela Adormecida".

Se temos na primeira obra o número oito como base, na segunda temos o número doze, os quais nos enviam a um ritual de passagem. Numa obra o oito simboliza o batistério, o encerrar uma etapa de vida a fim de tornar-se apta para outra; enquanto que na segunda obra temos o doze, símbolo da ordem cósmica e da salvação. Revive o misticismo pitagórico, porquanto "Somos herdeiros da Humanidade". Todavia Colasanti não se apropria gratuitamente desse misticismo; mas utiliza-se dele em contraposição à visão da mulher de "A Bela Adormecida", na medida em que desvenda o mito e liberta a mulher de seu sono milenar. Se em Perrault, essa surge passiva à espera de seu consciente, em Colasanti, surge como dona de seus próprios atos e corpo. Tem consciência de si e de seus atos. Não dorme à espera de seu príncipe e não aceita aquele que Ihe é destinado, mas traça o seu próprio destino, prova, averigua, constata. A mulher é posta na posição de consciente travando uma luta com o inconsciente coletivo na figura dos reis, tornando-se o príncipe "Consciente positivo-ativo herói vencedor da luta", contrapondo-se ao papel da mulher apresentada por Perrault, de "inconsciente passivonegativo". (99)

Se em Perrault, a mulher é "um arquétipo ou superinconsciente que vive na Memória do mundo...", em Doze Reis..., Colasanti mitifica para desmistificar. Em "A Bela Adormecida" a princesa é despertada para uma nova vida social pelo príncipe; enquanto que em "Doze Reis e a Moça no Labirinto do Vento", a mulher é quem desperta o rei, dita-lhe a hora, escolhe, aceitao; o que leva à supressão da figura de um príncipe, haja vista que a possuidora da consciência de que é chegada a hora, é a heroína.

Após esta breve comparação entre as obras, chegamos ao final compactuando com a visão de "Salústio" de que: "O Mundo é um objeto simbólico."(100), e que este simbolismo faz parte do inconsciente coletivo, sendo compartilhado por toda a humanidade. Aqui constatamos que 0 mito revela o pensamento de uma sociedade, bem como, sua concepção de existência e as relações que os homens mantêm entre si e com o mundo que os cerca, porque o mito pode ser obra dos homens mais é mais poderoso que eles. (101)

NOTAS DE REFERÊNCIA

1. ELIADE, Mircea. Mito e Realidade, p. 12.

2. ELIADE, Mircea. Mito e Realidade.

3. ELIADE, Mircea. Mito e Realidade, p. 75.

4. TODOROV, Tzvetan. Introdução à Literatura Fantástica.

5. PERRAULt, Charles. A Bela Adormecida. Col. Fant. V. 4 p. 21.

6. ELIADE, Mircea. O Sagrado e o Profano.

7. ELIADE, Mircea. O Sagrado e o Profano, p. 175.

8.PERRAULT, Charles. A Bela Adormecida. Col. Fant. V. 4, p. 21. 
9.CIRLOT, Juan-Eduardo. Dicionário de Símbolos.

10. PERRAULT, Charles. A Bela Adormecida. Col .Fant. v. 4, p. 21.

11.ELIADE, Mircea. O Sagrado e o Profano, p. 188

12. .Idem 10.

13. Idem 10.

14. PERRAULT, Charles. A Bela Adormecida. Col. Fant. V. 4, p. 21.

15. Idem 14.

16. Idem 14.

17. Idem 14.

18. PERRAULT, Charles. A Bela Adormecida. Col. Fant., v. 4, p. 21.

19. PERRAULT, Charles. A Bela Adormecida. Col. Fant., v. 4, p. 21.

20. CIRLOT, Juan-Eduardo. Dicionário de Símbolos, p. 412-413.

21. PERRAULT, Charles. A Bela Adormecida. Col Fant., v. 4, p. 21.

22. PERRAULT, Charles. A Bela Adormecida. Col. Fant., v. 4, p. 21.

23. PERRAULT, Charles. A Bela Adormecida. Col. Fant., v. 4, p. 21.

24. ZANLORENZI, Ivo. Lições de Filosofia. P. 102-103.

25. PERRAULT, Charles. A Bela Adormecida. Col. Fant., v. 4, p. 21.

26. RONAN, Colin A. História llustrada da Ciência.

27. PERRAULT, Charles. A Bela Adormecida. Col. Fant., v. 4, p. 21.

28. PERRAULT, Charles. A Bela Adormecida. Col. Fant., v. 4, p. 21-23-24.

29. PERRAULT, Charles. A Bela Adormecida. Col. Fant., v. 4, p. 24.

30. RONAN, Colin A. História llustrada da Ciência in Das Origens à Grécia. v. 1.

31. BAE, G. Fraide. Historia de la Filosofia.

32. PERRAULT, Charles. A Bela Adormecida. Col. Fant., v. 4, p. 21.

33. CIRLOT, Juan-Eduardo. Dicionário de Símbolos, p. 157.

34. PERRAULT, Charles. A Bela Adormecida. Col. Fant., v. 4, p. 34.

35. CIRLOT, Juan-Eduardo. Dicionário de Símbolos, p. 573.

36. PERRAULT, Charles. A Bela Adormecida. Co. Fant., v. 4, p. 34.

37. CIRLOT, Juan-Eduardo. Dicionário de Símbolos, p. 211-212.

38. CIRLOT, Juan-Eduardo. Dicionário de Símbolos, p. 75.

39. PERRAULt, Charles. A Bela Adormecida. Col. Fant., v. 4, p. 34.

40. CIRLOT, Juan-Eduardo. Dicionário de Símbolos.

41. ELIADE, Mircea. Mito e Realidade, p. 80.

42. CIRLOT, Juan-Eduardo. Dicionário de Símbolos, p. 258-259.

43. ELIADE, Mircea. O Sagrado e o Profano, p. 140.

44. CIRLOT, Juan-Eduardo. Dicionário de Símbolos, p. 216.

45. PERRAULt, Charles. A Bela Adormecida. Col. Fant., v. 4, p. 36.

46. PERRAULT, Charles. A Bela Adormecida. Col. Fant., v. 4, p. 38.

47. CIRLOT, Juan-Eduardo. Dicionário de Símbolos, p. 101-102.

48. HERÁCLITO, fragmento no 93 - segundo Hermann Drils.

49. PERRAULt, Charles. A Bela Adormecida. Col. Fant., v. 4, p. 38.

50. PERRAULT, Charles. A Bela Adormecida. Col. Fant., v. 4, p. 38.

51. CIRLOT, Juan-Eduardo. Dicionário de Símbolos, p. 131.

52. CIRLOT, Juan-Eduardo. Dicionário de Símbolos, p. 537.

53. PERRAULT, Charles. A Bela Adormecida. Col. Fant., v. 4, p. 38.

54. PERRAULT, Charles. A Bela Adormecida. Col. Fant., v. 4, p. 38.

55. PERRAULT, Charles. A Bela Adormecida. Col. Fant., v. 4, p. 40.

56. PERRAULT, Charles. A Bela Adormecida. Col. Fant., v. 4, p. 41.

57. PERRAULT, Charles. A Bela Adormecida. Col. Fant., v. 4, p. 41.

58. PERRAULT, Charles. A Bela Adormecida. Col. Fant., v. 4, p. 42.

59. JUNG, Carl e outros. O Homem e seus Símbolos. p. 129.

60. PERRAULT, Charles. A Bela Adormecida. Col. Fant., V. 4 P. 42.

61. PERRAULT, Charles. A Bela Adormecida. Col. Fant., v. 4, p. 43.

62. FRANZ, Marie-Louise von. A Sombra e o Mal, p. 111.

63. PERRAULT, Charles. A Bela Adormecida. Col. Fant. V. 4, p. 43.

64. CIRLOT, Juan-Eduardo. Dicionário de Símbolos, p. 355-356.

65. PERRAULT, Charles. A Bela Adormecida. Col. Fant., v. 4, p. 43.

66. CIRLOT, Juan-Eduardo. Dicionário de Símbolos, p. 206.

67. PERRAULT, Charles. A Bela Adormecida. Col. Fant., v. 4, p. 45.

68. PERRAULT, Charles. A Bela Adormecida. Col. Fant., v. 4, p. 45. 
69. COLULANGES, Fustel de. A Cidade Antiga. In terceiro livro: A Cidade, p. 136.

70. COLASSANTI, Marina. Doze Reis e a Moça no Labirinto de Vento, ibidem, p. 41.

71. CIRLOT, Juan-Eduardo. Dicionário de Símbolos, p. 85-86-329-330-99.

72. CIRLOT, Juan-Eduardo. Dicionário de Símbolos, p. 595.

73. COLASSANTI, Marina. Doze Reis e a Moça no Labirinto de Vento, ibidem, p. 41.

74. BULFINCH, Thomas. O Livro da Mitologia.

75. COLASSANTI, Marina. Doze Reis e a Moça no Labirinto do Vento, ibidem p. 41.

76. CIRLOT, Juan-Eduardo. Dicionário de Símbolos. p. 595.

77. COLASSANTI, Marina. Doze Reis e a Moça no Labirinto do Vento, ibidem, p. 41.

78. CIRLOT, Juan-Eduardo. Dicionário de Símbolos.

79. CIRLOT, Juan-Eduardo. Dicionário de Símbolos, p. 427-428.

80. COLASSANTI, Marina. Doze Reis e a Moça no Labirinto do Vento, ibidem p. 41.

81. COLASSANTI, Marina. Doze Reis e a Moça no Labirinto do Vento, ibidem p. 41.

82. CIRLOT, Juan-Eduardo. Dicionário de Símbolos, p. 304.

83. COLASSANTI, Marina. Doze Reais e a Moça no Labirinto do Vento, p. 42.

84. CIRLOT, Juan-Eduardo. Dicionário de Símbolos, p. 412.

86. COLASSANTI, Marina. Doze Reis e a Moça no Labirinto do Vento, ibidem p. 42.

87. COLASSANTI, Marina. Doze Reais e a Moça no Labirinto do Vento, ibidem p. 42.

88. CIRLOT, Juan-Eduardo. Dicionário de Símbolos, p. 136-137.

89. CIRLOT, Juan-Eduardo. Dicionário de Símbolos, p. 412.

90. COLASSANTI, Marina. Doze Reis e a Moça no Labirinto do Vento, p. 43.

91. CIRLOT, Juan-Eduardo. Dicionário de Símbolos, p.91-256.

92. COLASSANTI, Marina. Doze Reis e a Moça no Labirinto de Vento, p. 43.

93. COLASSANTI, Marina. Doze Reis e a Moça no Labirinto de Vento, p. 46.

94. CIRLOT, Juan-Eduardo. Dicionário de Símbolos, p. 130.

95. CIRLOT, Juan-Eduardo. Dicionário de Símbolos, p. 236.

96. CIRLOT, Juan-Eduardo. Dicionário de Símbolos, p. 414.

97. CIRLOT, Juan-Eduardo. Dicionário de Símbolos, p. 414-415.

98. COLASSANTI, Marina. Doze Reis e a Moça no Labirinto do Vento, ibidem, p. 46.

99. CARVALHO, Bárbara Vasconcelos. A Literatura Infantil. 4⿳a ed. Ed. Global - p. 66-67.

100. CIRLOT, Juan-Eduardo. Dicionário de Símbolos. Ed. Moraes p. 1.

101. ROCHA, Everardo. O Que é Mito.

\section{BIBLIOGRAFIA}

BULFINCH, Thomas. O LIVRO DE OURO DA MITOLOGIA - The Age of Fable. - 1ª Ed. Tradução: David Jardim Júnior. São Paulo / Ed. Ediouro./1965/

CARVALHO, Bárbara Vasconcelos de. A LITERATURA INFANTIL: visão histórica. 4ª ed. São Paulo - Global / 1985

CIRLOT, Juan-Eduardo. DICIONÁRIO DE SÍMBOLOS - Tradução Rubens Eduardo Ferreira Frias. 1ª Ed. São Paulo - Editora Moraes. / 1984 /

COLASANTI, Marina - DOZE REIS E A MOÇA NO LABIRINTO DO VENTO. 1ª. Ed. São Paulo - Círculo do Livro. /1988/

COULANGES, Fustel de - A CIDADE ANTIGA. La Cité antique. Tradução: Fernando de Aguiar. São Paulo: Martins Fontes /1981/

ELIADE, Mircea - MITO E REALIDADE. - Myth And Reality. Tradução; Pola Civetti. - São Paulo - Ed. Perspectiva. /1972/ Coleção

Debates - Filosofia - Vol. 52

ELIADE, Mircea - O SAGRADO E O PROFANO. A Essência das Religiões. Das Heilige Und das Profene. Tradução: Rogério

Fernando. Lisboa, Edição 'livros do Brasil" Lisboa - Coleção Vida e Cultura. Vol. 62

FEIJÓ, Martin Cezar. - O QUE É HERÓI. 1a Ed. São Paulo. - Ed. Brasiliense./1984/ Coleção Primeiros Passos - Vol. 139

FRAILE, Guilhermo. - HISTÓRIA DE LA FILOSOFÍA. Madri - 5ª Ed. La Editorial Catolica S/ㅍ /1982/ - Biblioteca de Autores

Cristianos. Vol. I.

JUNG, Carl G. - O HOMEM E SEUS SímBOLOS. - Tradução Maria Lúcia Pinho. 3a ed. - Rio de Janeiro - Ed. Nova Fronteira. /1982/ PERRAULT, Charles - 'A BELA ADORMECIDA'.- versão. Organização de texto: Paulo Matos Peixoto. São Paulo - Ed. Paumape Coleção Fantasia - Vol. IV

ROCHA, Everardo P.G. - O QUE É MITO - 1ª Ed. São Paulo - Ed. Brasiliense/1984/ Coleção Primeiros Passos - Vol. 151

RONAN, Colin a - HISTÓRIA ILUSTRADA DA CIÊNCIA da Universidade de Cambrige. Das Origens à Grécia. 1ª Ed. São Paulo -

Círculo do Livro. Vol. I

TODOROV, Tzvetan - INTRODUÇÃO À LITERATURA FANTÁSTICA. - Introduction à la litterature fantastique. Tradução: Maria

Clara Correa Castello. - São Paulo - Ed. Perspectiva./1975/ - Coleção Debates - Teoria da Literatura - Vol. 98

VON FRANZ, Marie-Louise. - A SOMBRA E O MAL NOS CONTOS DE FADA - Shadow And Evil in Fairtales. Tradução: Maria

Christina Penteado Kujawski. - São Paulo. Ed. Paulinas./1985/ Coleção Amor e Psique. 
